\title{
KLINIČKE KARAKTERISTIKE PLUĆNE DISFUNKCIJE U CIROZI JETRE
}

\author{
CLINICAL CHARACTERISTICS OF PULMONARY DISFUNCTION IN LIVER CIRRHOSIS
}

\section{Zoran Mavija,Milka Mavija,Slavko Grbić, Božo Krivokuća, Rajkica Bambulović- Petrović}

\begin{abstract}
Sažetak: Plućni poremećaji i simptomi su često prisutni u pacijenata sa cirozom jetre, a trećina pacijenata sa dekompenzovanom cirozom ima hipoksemiju. U najvećem procentu pacijenata sa dekompenzovanom cirozom jetre plućnu disfunkciju prati respiratorna alkaloza, posebno u odmaklom stadijumu bolesti. Ovo stanje ima značajan uticaj na kvalitet $i$ dužinu života ovih pacijenata.

Cil rada je utvrditi kliničke karakteristike plućne disfunkcije kod pacijenata sa dekompenzovaom cirozom jetre i ukazati na značaj ovog poremećaja. Prilikom istraživanja korišten je poseban, specijalno dizajniran protokol ispitivanja u koji su se bilježili svi relevantni podaci vezani za istraživanje: $U$ istraživanje je uključeno 50 pacijenata sa cirozom jetre, $66 \%$ ispitanika je bilo u stadijumu Child C, a $34 \%$ ispitanika je bilo u stadijumu Child B ciroze jetre. Od ukupnog broja pacijenata predstavnika muškog pola je 76\%, pri čemu je srednja životna dob ispitanika iznosila 58,6士10,5 godina. Gušenje kao dominantni simptom plućne disfunkcije je bilo prisutno kod 30\% pacijenata, dok je hipoksemija verifikovana kod 32\% pacijenata. Alkalozu je bila prisutna kod 12\% ispitanika, dok je acidoza bila prisutna kod 4\% ispitanih. Pleuralni izlivi su utvrđeni kod $12 \%$ ispitanika.

Pacijenti sa izraženim poremećajima plućne disfunkcije imaju teži stadijum ciroze jetre. Poznavanje etiologije, rana dijagnostika i odgovarajući tretman su od izuzetne važnosti za poremećaje plućne disfunkcije kod ciroze jetre.
\end{abstract}

Ključne riječi: ciroza jetre, plućna disfunkcija, hipoksemija, respiratorna alkaloza

\section{UVOD}

Povezanost plućne disfunkcije i bolesti jetre je bila prepoznata prije više od sto godina. Još je 1884. godine Fluckiger prvi opisao ženu sa cirozom jetre, cijanozom i batićastim prstima. Poslije je Rydell 1956. godine prvi našao dilatirane plućne arterije i široke komunikacije između plućnih arterija i vena u području hilusa i pleure u osobe $s$ juvenilnom cirozom i sniženom saturacijom kiseonikom. Ciroza jetre može da mijenja disajne funkcije dovodeći do promjena u pleuri i abdomenu, ili neposredno izazivajući patološke promjene $u$ samim plućima. Bolesnici sa oboljenjem jetre veoma često imaju poremećaj plućne funkcije, a trećina sa dekompenzovanom cirozom ima hipoksemiju. Značaj detekcije plućne disfunkcije u pacijenata sa cirozom jetre proizilazi iz brojnih studija u pacijenata koji imaju hepatičku i plućnu disfunkciju. Plućni poremećaji i simptomi su često prisutni u pacijenata sa cirozom jetre (1).

U skrining studijama pacijenata sa cirozom jetre, poremećaji arterijske oksigenacije su nađeni kod $45 \%$ ispitanika. Hipoksemija u oboljenjima jetre je multifaktorske geneze i može biti uzrokovana pleuralnim izlivima (hepatički hidrotoraks), plućnom hipertenzijom, parenhimskom plućnom disfunkcijom, bronhitisom ili emfizemom izazvanim pušenjem, portno-plućnim šantovima, smanjenim afinitetom hemoglobina za kiseonik, alveolnokapilarnim poremećajem difuzije, ventilacionoperfuzionom nepodudarnošću i/ili intrapulmonalnim arterio-venskim šantovima (2). U nastanku arterijske hipoksemije važan uzrok predstavljaju intrapulmonalni arteriovenski šantovi na osnovu čega Kennedy i Knudson, predlažu da se uvede termin hepatopulmonalni sindrom (HPS). Hepatopulmonalni sindrom je definisan oboljenjem jetre, hipoksemijom, povećanjem alveolnoarterijskog gradijenta tokom udisanja atmosferskog 
vazduha i intrapulmonalnom vaskularnom dilatacijom (IPVD). Uzroci nastanka intrapulmonalne vaskularne dilatacije, koja čini osnov HPS-a nisu dovoljno poznati. Smatra se da suštinski patofiziološki mehanizmi predstavljaju poremećaj odnosa između vazodilatatornih i vazokonstriktornih supstanci koji može nastati zbog: nemogućnosti oboljele jetre da eliminiše cirkulišuće vazodilatatore usljed oštećene metaboličke i detoksikacione funkcije, oštećene sintetske funkcije jetre sa produkcijom cirkulišućih vazodilataora i/ili inhibicije cirkulišućih vazokonstriktornih supstanci (3). Patoanatomski susptrat intrapulmonalne vaskularne dilatacije čine dilatisani prekapilari, direktne arterio-venske komunikacije i dilatirani pleuralni krvni sudovi. Kod pacijenata sa cirozom jetre i izraženom hipoksemijom, intrapulmonalni desno- lijevi šantovi predstavljaju glavni patogenetski mehanizam u nastanku teških respiratornih poremećaja. Hipoksemija se naročito manifestuje u sjedećem položaju.

Hiperventilisanje, hipokapnija sa respiracijskom alkalozom čest je poremećaj respiracijskih gasova u oboljelih od ciroze (4). Blaga hipoksemija se nalazi $\mathrm{u}$ oko trećine oboljelih od ciroze jetre. Znatna hipoksemija znači, da je kod bolesnika razvijen hepatopulmonalni sindrom, ili je pridruženo još neko oboljenje pluća ili srca. Ne postoji jedinstveno mišljenje o incidenci oksigenacionih poremećaja $u$ cirozi jetre. Vrijednosti $\mathrm{Pa} 02$ manje od $9,3 \mathrm{kPa}$ ukazuju na značajan plućni poremećaj, a teška hipoksemija sa $\mathrm{Pa} 02$ ispod $6,6 \mathrm{kPa}$ upućuje na dijagnozu HPS-a (5).

Dispneja je najčešći plućni simptom koja se javlja kod $40 \%$ pacijenata sa dekompenzovanom cirozom jetre. Kada se uz oštećenje jetre pojavi otežano disanje, koje se u početku javlja u naporu, a kasnije je izražena dispneja u uspravnom položaju, treba pomisliti na plućne komplikacije jetrene ciroze. Veoma karakteristična pojava, vezana za intrapulmonalne šantove jeste platipnea, koja označava dispneju u stojećem ili sjedećem položaju u odnosu na ležeći. Često postoji i cijanoza uz batićaste prste (6).

U nastanku pleuralnog izliva kod pacijenata sa cirozom jetre utiče više patogenetskih mehanizama, kao: hipoalbuminemija i pad koloidno osmotskog pritiska, formiranje kolateralnh anastomoza između portnog i azigos sistema sa posljedičnom transudacijom tečnosti, transudacija limfe iz ductus thoracicusa, prelazak tečnosti iz abdominalne šupljine u pleurani prostor kroz limfatičke kanale dijafragme, i direktan protok peritonealne tečnosti kroz dijafragmalne defekte. Jednosmjerni protok tečnosti iz abdomena u grudni koš objašnjava se valvularnim mehanizmom koji funkcioniše na osnovu razlike pritiska. Tečnost se kreće iz abdomena, gdje vlada pozitivan pritisak, u pravcu grudnog koša, gdje se, u zavisnosti od respiratornog ciklusa, registruje negativan pritisak (7). U nekim studijama ističe se da su kongenitalni dijafragmalni defekti i porast intraabdominalnog pritiska najvažniji precitipirajući faktori za nastanak hepatičnog hidrotoraksa. Obično je riječ o veoma malim defektima promjera od 0,03 do $0,12 \mathrm{~mm}$, mada mogu biti i veći od $5 \mathrm{~mm}$. Veliki pleuralni izlivi koji zasjenjuju veći dio plućnog krila $u$ odsustvu primarne ili plućne ili srčane bolesti, definišu se kao hepatički hidrotoraks. Prevashodno se razvija s desne strane, dok se bilateralna efuzija javlja znatno rjeđe. Pleuralni izliv može se naći u najmanje $10 \%$ pacijenata sa cirozom jetre. Pacijente najviše ugrožavaju veliki izlivi koji pomjeraju srce u kontralateralnu stranu i izlivi koji, zbog uticaja gravitacije, ometaju funkciju dijafragme (8).

$\mathrm{Za}$ procjenu funkcionalnog stanja jetre bolesnika sa cirozom jetre korist se Childova klasifikacija. Parametri koji se prate u ovoj klasifikaciji su: prisustvo ascitesa, stepen hepatičke encefaloaptije, vrijednosti bilirubina, albumina $\mathrm{i}$ vrijednost INR-a. $\mathrm{Na}$ osnovu skoring sistema navedenih parametara razlikujemo tri stadija ciroze jetre A, B i C. Stadiji B i C su teže forme ciroze jetre i prognostički nepovoljnije.

\section{CILJ RADA}

Cilj istraživanja je utvrditi kliničke karakteristike plućne disfunkcije u dekompenzovanoj cirozi jetre i ukazati na značaj ovog poremećaja koji često ostaje nedovoljno dijagnostikovan.

\section{METODE}

Ispitivanje po tipu prospektivne studije provedeno je na Odjeljenju gastroenterologije i hepatologije, Klinike za unutrašnje bolesti, Univerzitetskog kliničkog centra Republike Srpske u Banja Luci. Uzorak istraživanja čini grupa od 50 pacijenata koji su hospitalizovani zbog ciroze jetre.

Da bi bili uključeni u ispitivanje pacijenti su 
morali zadovoljiti slijedeće kriterije: da imaju dijagnostikovanu dekompenzovanu cirozu jetre različite etiologije $\mathrm{i}$ da su stariji od 18 godina. Kriteriji za isključivanje iz ispitivanja su kompenzovana ciroza jetre bez prisutnih komplikacija i pacijenti mlađi od 18 godina. Svi pacijenti su zadovoljili kriterije ispitivanja.

Prilikom istraživanja korišten je poseban, specijalno dizajniran protokol ispitivanja u koji su se bilježili svi relevantni podaci vezani za istraživanje: generalije ispitanika, anamnestički podaci, podaci o subjektivnim tegobama pacijenata, podaci o kliničkim znacima bolesti, laboratorijske analize, nalazi dijagnostičkih procedura (standardna radiografija grudnog koša i srca -RTG , ultrazvuk abdomena, ezofagogastroduodenoskopija) i eventualne dodatne pretrage (kompjuterizovana tomografija-CT $\mathrm{i} / \mathrm{ili}$ nuklearna magnetna rezonanca-NMR abdomena, doppler ultrasonografija jetre, slezene i portnog sistema). Odmah po prijemu je urađen detaljan fizikalni pregled, uzeta krv za kompletnu analizu, urađen je RTG grudnog koša, ultrasonografija abdomena i ezofagogastroduodenoskopija. Rezultati su obrađeni standardnim statističkim metodama i prikazani su tabelarno i grafički..

\section{REZULTATI}

Ispitivanjem je obuhvaćeno 50 pacijenata sa dijagnozom dekompenzovane ciroze jetre. Među svim ispitanicima je bilo 38 (76\%) osoba muškog pola i 12 (24\%) osoba ženskog pola.

Pacijenti su analizirani i u odnosu na životnu dob. Srednja životna dob je iznosila 58,6 $\pm 10,5$ godina. Od svih 50 ispitanika sa cirozom jetre najčešće je registrovana alkoholna ciroza i to kod 42 ispitanika (84\%), virusna ciroza jetre je utvrđena kod 7 ispitanika (14\%), a autoimuna ciroza kod 1 ispitanika (2\%). Značajno veći procenat ispitanika (66\%) je bilo u odmaklom stadijumu ciroze jetre Child C, dok je $34 \%$ ispitanika bilo u stadijumu Child B ciroze jetre. Rezultati su prikazani u tabeli 1 .

\begin{tabular}{|c|c|c|}
\hline Karakteristika & $\begin{array}{l}\text { Broj } \\
N\end{array}$ & $\begin{array}{c}\text { Procenat } \\
\%\end{array}$ \\
\hline Ukupan br. ispi & & 100,0 \\
\hline \multicolumn{2}{|c|}{ Starost (srednja vrijednost \pm SD) } & \\
\hline Pol Muškarc & 38 & 76,0 \\
\hline Žene & 12 & 24,0 \\
\hline
\end{tabular}

\begin{tabular}{lcc}
\hline Etiologija ciroze & & \\
Alkoholna & 42 & 84,0 \\
Virusna & 7 & 14,0 \\
Autoimuna & 1 & 2,0 \\
\hline Stadij ciroze & & \\
Child B & 33 & 66,0 \\
Child C & 17 & 34,0 \\
\hline
\end{tabular}

Pacijenti sa dekompenzovanom cirozom jetre često se žale na respiratorne tegobe. Gušenje kao dominantni respiratorni simptom je bilo prisutno kod $15(30 \%)$ ispitanika (Grafikon1).

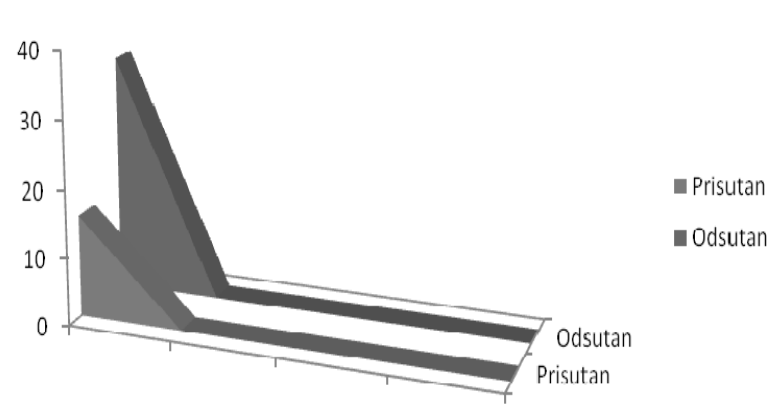

Grafikon 1. Prisutnost simptoma gušenja kod ispitanika

Gasna analiza krvi je osnovna dijagnostička metoda u cirozi jetre sa poremećajem oksigenacije. Hipoksemija je verifikovana kod $16 \quad(32 \%)$ ispitanika, dok je hipokapnija verifikovana kod 8 $(16 \%)$ ispitivanih $\mathrm{u}$ ovom istraživanju. Kod preostalih $26(52 \%)$ ispitanika rezultati gasne analize su bili unutar referentnih vrijednosti (Grafikon 2).

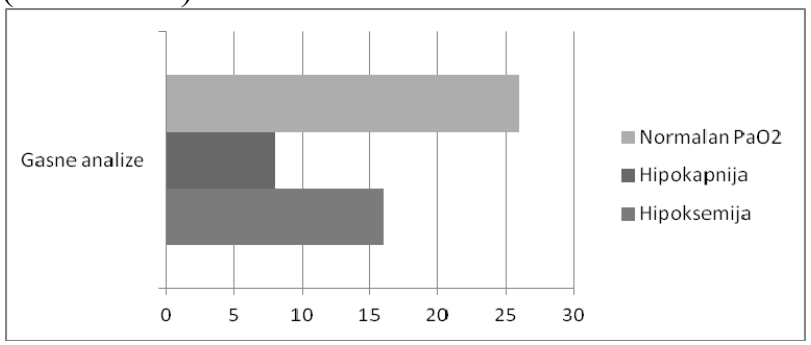

Grafikon 2. Gasna analiza kod ispitanika

$\mathrm{U}$ odnosu na vrijednost $\mathrm{Pa} 02$ kod svih ispitanika sa prisutnom hipoksemijom, blaga hipoksemija sa vrijednošću $\mathrm{Pa} 02$ manjom od 9,3 kPa je bila prisutna kod skoro dve trećine ispitivanih $6(37,5 \%)$, dok je teška forma hipoksemije sa vrijednošću $\mathrm{Pa}_{2}$ manjom od $6,6 \mathrm{kPa} \mathrm{kPa}$ bila verifikovana kod preostale 1/3 ispitivanih. Svi ispitanici sa teškom formom hipoksemije bili su iz grupe sa alkoholnom cirozom jetre. 
Cirozu jetre sa ispoljenom plućnom disfunkcijom prate rezličiti poremećaji acidobaznog statusa. Alkaloza je bila prisutna kod 6 (12\%) ispitanika, dok je acidoza bila prisutna kod 2 (4\%) ispitanika. Kod preostalih 42 (84\%) ispitanika nisu evidentirani poremećaji acidobaznog statusa (Grafikon 3).

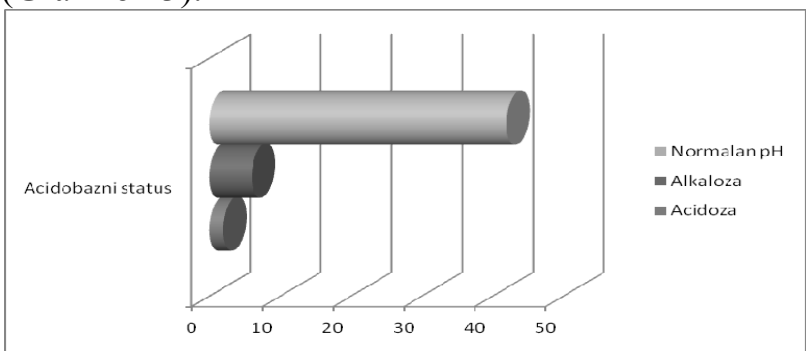

Grafikon 3. Acidobazni status ispitanika sa cirozom jetre

Istraživanjem je utvrđeno da u najvećem broju slučajeva $\mathrm{i}$ to kod $44(88 \%)$ ispitanika nalaz standarne radiografije grudnog koša bio uredan, dok u $6 \quad(12 \%)$ slučajeva ispitanici imaju desnostrani pleuralni izliv Nisu verifikovani obostrani ili lijevostrani pleuralni izlivi.

\section{DISKUSIJA}

Ciroza jetre je progresivna bolest koju karakteriše kompleksna simptomatologija. Ukupno je ispitano 50 pacijenata, pri čemu je $76 \%$ ispitanika bilo muškog pola, dok su žene zastupljene u $24 \%$ slučajeva ispitanika. Svi ispitivani pacijenti su značajno starije dobi. Literaturni dostupni podaci govore o predominaciji muškog pola i starijoj životnoj dobi pacijenata sa cirozom $(9,10)$.

Alkoholna i posthepatitisna ciroza jetre najčešći su uzroci oboljenja u razvijenim zemljama svijeta. Alkoholno oštećenje jetre danas je izuzetno česta pojava koja ima važnu ulogu u opštem morbiditetu i mortalitetu, Toj grupi pripada i prostor Republike Srpske koja ima veliki broj alkoholičara, i gdje je alkoholizam kao medicinski problem već dugo prisutan. Dobiveni rezultati su u skladu sa podacima iz literature (11).

Pacijenti sa cirozom jetre najčešće se žale na gušenje. U početnom stadijumu oboljenja gušenje se pojavljuje pri naporu, a često je izražena platipnoa tj. nedostatak vazduha u uspravnom položaju. Smatra se da platipnoa nastaje zbog gravitacijske sile koja pri uspravnom stavu povećava protok kroz bazalne dijelove pluća i pogoršava shuntove. U ovom istraživanju, gušenje je bilo prisutno kod 30\% ispitanika, što je u skladu sa literaturnim podacima $(12,13)$.

Različit spektar plućnih gasnih promjena može se naći u pacijenata sa odmaklom cirozom jetre, stoga su poremećaji u gasnoj analizi uobičajeni u ovih ispitanika. Ne postoji jedinstveno mišljenje o incidenci oksigenacionih poremećaja u cirozi jetre. Vrijednosti $\mathrm{Pa} 02$ manje od $9,3 \mathrm{kPa}$ ukazuju na značajan plućni poremećaj, a teška hipoksemija sa $\mathrm{Pa}_{2}$ ispod $6,6 \mathrm{kPa}$ upućuju na tešku hipoksemiju. Dosta česta promjena u cirozi jetre je hipokapnija koja je zabilježena kod $73 \%$ cirotičnih pacijenata sa plućnom vazodilatacijom, što su verifikovali pojedini autori $(14,15)$. Plućna vazodilatacija je mnogo češća $i$ teža u pacijenata sa uznapredovalom hepatotocelularnom disfunkcijom.

Stanje bolesti jetre i zahvaćenost pluća ne moraju korelisati, te se može dogoditi da uz dobru hepatalnu funkciju postoji izražena hipoksemija. Cirozi jetre je često pridružena arterijska hipoksemija u odsutnosti kardiopulmonalne bolesti, ali patogeneza ovog poremećaja je još uvijek nepoznata. Pretpostavljeni mehanizam hipoksemije uključuje intra $\mathrm{i} / \mathrm{ili}$ extrapulmonalne šantove, poremećaje ventilacije-perfuzije i poremećaje kapilarne difuzije. Postavlja se pitanje koji je od ovih nabrojanih faktora najvažniji. Hipoksemiji u oboljelih od ciroze jetre doprinosi i konzumiranje alkohola. Dobijene nalaze pogoršava pušenje cigareta. Jednonedjeljna apstinecija od alkohola bila je dovoljna da dovede do poboljšanja parcijalnog pritiska kiseonika. Prevalenca hipoksemije iz literaturnih podataka varira od $22 \%$ do $70 \%$. To dijelom može biti povezano sa kardijalnom ili plućnom disfunkcijom, međutim bolest jetre i njene komplikacije takođe imaju značajnu ulogu u poremećajima oksigenacije (16).

Hipoksemija je dijagnostikovana kod $32 \%$ ispitanika sa dekompenzovanom cirozom jetre, dok je hipokapnija dijagnostikovana kod $16 \%$ ispitanika $\mathrm{u}$ ovom istraživanju plućne disfunkcije. I drugi autori navode slične rezultate $u$ svojim istraživanjima (17).

Poremećaji acidobzne ravnoteže $(\mathrm{pH}) \mathrm{u}$ ekstracelularnoj tečnosti su značajni pratioci ciroze jetre. Kod ovih pacijenata su mogući razlčiti premećaji $\mathrm{pH}$ vrijednosti. U hroničnim oboljenjima jetre jedan od najčešćih poremećaja je alkaloza. 
Vjerovatnim uzrokom nastanka respiratorne alkaloze treba smatrati hiperventilaciju, otvaranje intrapulmonalnih šantova i hiperamonijemiju. U slučaju teških poremećaja funkcije jetre koji prate dekompenzovanu cirozu mogu se javiti i kombinovani poremećaji acidobazne ravnoteže. Respiratornu aklakozu je u ovom istraživanju imalo $15 \%$ pacijenata, dok je acidozu imalo $5 \%$ pacijenata. Dobijeni rezultati su u skladu sa literaturnim podacima (18).

U nastanku pleuralnog izliva kod pacijenata sa cirozom jetre involvirani se brojni patogenetski mehanizami. RTG grudnog koša je urađen svim pacijentima. U ovom ispitivaju kod $12 \%$ ispitanika sa dekompenzovanom cirozom jetre verifikovan je desnostrani pleuralni izliv. Samo rijetko postoji jednostrani izlivi sa lijeve strane, i oni su česti kod tuberkuloze. Nisu verifikovani obostrani ili lijevostrani pleuralni izlivi. Dobijeni podaci u ovom ispitivanju su u skladu sa dostupnim podacima iz lietrature (19).

\section{ZAKLJUČAK}

U najvećem procentu pacijenata sa dekompenzovanom cirozom jetre plućnu disfunkciju prati respiratorna alkaloza, posebno u odmaklom stadijumu bolesti. Na osnovu kliničkih parametara možemo zaključiti da pacijenti sa izraženim poremećajima plućne disfunkcije imaju teži stepen ciroze jetre. Poznavanje etiologije, rana dijagnostika i odgovarajući tretman su od izuzetne važnosti za poremećaje plućne disfunkcije kod odmakle ciroze jetre. Poremećaji plućne disfunkcije u cirozi jetre imaju značajan uticaj na kvalitet i dužinu života pacijenata.

\section{LITERATURA}

1. Kochar R, Nevah Rubin MI, Fallon MB. Pulmonary complications of cirrhosis. Current Gastroenterology Reports 2011;13:34-9.

2. Schenk P, Schoniger-Hekele M, Fuhmann V, et al. Prognostic significance of the hepatopulmonary sindrome in patients with cirrhosis. Gastronterology 2003;125:1042

3. Sussman NL, Kochar R, Fallon MB. Pulmonary complications in cirrhosis. Current Opinion in Organ Transplantation 2011;16:261-88.
4. Abraldes JG, Tarantino I, Turnes J, et al. Hemodynamic response to pharmacologic treatment of portal hypertension and long-term prognosis of cirrhosis. Hepatology 2003; 37:902-8.

5. Fintz JS, Fallon MB, Kawut SM. Pulmonary vascular complications of Liver Disease. Am J Respir Care Med. Chest 2013:187;133-43.

6. Argudeas MR, Singh H, Faulk DK, Fallon MB. Utility of pulse oximetry screening for hepatopulmonary syndrom. Clin Gastroenterol Hepatolo 2007: 5:749.

7. Alberts WM, Salem AJ, Solomon DA, Boyce G. Hepatic hydrothorax. Arch Int Med 1991;151:23838.

8. Younis I, Sarwar S, Butt Z, et al. Clinical characteristics, predictors, and survival among patients with decompensated chronic liver disease and its impact on short-term survival. Arg Gastroenterol 2008; 45:34.

9. Donato F, Tagger A, Gellati U, Parrinelo G, Bolfetta $\mathrm{P}$, Albertini A, et al. Alcohol and hepatocellular carcinoma: the effect of lifetime intake and hepatitis virus infections in man and women. Am J Epidemiol 2002;155:321-31.

10. Fussner LA, Iyer VN, Cartin-Ceba $R$, et al. Intrapulmonary vascular dilatation are commom in portopulmonary hypertension and may be associated with decreased survival. Liver transpl 2015; $21: 1355$.

11. Scott VL, Dodson SF, King Y. The hepatopulmonary syndrome. Surg Clin North Am 1999;79(1):23-41.

12. Krowka MJ. Hepatopulmonary syndrome. Gut 2000; 46(1): 1-4.

13. Gorgy AI, Jonassaint NL, Stanley SE, et al. Hepatopulmonary syndrome is a frequent cause of dyspnea in telomere disordes. Chest 2015; 148:1019.

14. Rodriguez-Roisin R, Krowka MJ. Hepatopulmonary syndrome-a liver-induced lung vascular disorder. N Engl J 2006; 358:2378

15. Grace JA, Angus PW, Hepatopulmonary syndrome. Update on recent advances in pathophysiologi, investigation, and treatment. J Gastroenterol Hepatol 2013;28-213.

16. Khabbaza JE, Krasuski RA, Tonelli AR. Intrapulmonary shunt corfimed by intracardiac diagnosis of hepatupulmonary syndrome. Hepatology 2013; 58:1514.

17. Krowka MJ, et al. Pulmonary contraindications, indications and MELD exceptions for liver transplantation. A contemporary view and look forward. Journal of Hepatology 2013;59:367. 
18. Ier VN, Krasuski RA, et al. Hepatopulmonary syndrome: Favorable outcomes in the MELD exception era. Hepatology 2013; 57:2427.

19. Fallon MB, Krowka MJ, Brown RS, Trotier JF, Zacks S Roberts KE, et al. Impact of hepatopulmonary syndrome on quality of life and survival in liver transplant candidates. Gastroenterology 2008;135:1168-75.

Summary: Pulmonary disfunction and symptoms are often present in patients with liver cirrhosis and one-thir of them with decompensated liver cirrhosis have hypoxemia as well. The highest percentage of patients with decompensated liver cirrhosis, pulmonary disfunction are associated with respiratory alkalosis., especially in advanced stage of disease. This condition has a significant impact on the quality and the length of life of these patients.

The aim of this paper is to determine the clinical characteristics of pulmonary disfunction patients with decompensated liver cirrhosis and highlight the importance of this disorders. During research was used specially designed protocol in which were entered all relevant data related to research. The study included patients with liver cirrhosis, of which 66\% were in Child C stage of liver cirrhosis, and 34\% were in Child B stage. Of the total number patients, representatives of the male gender were $76 \%$, wherein the mean age of patients was 58,6 $\pm 10,5$. Dyspnoea as a dominant symptoms of pulmonary disfunction occurred in $30 \%$ of patients, while hypoxemia verified in $32 \%$ of patients. Alkalosis was present in $12 \%$ of patients, while acidosis was present in $4 \%$ of respondents. Pleural effusions were found in $12 \%$ of patients.

Patients with distinct disorder of pulmonary function have more advanced stage of liver disease. Knowing etiology, early diagnostics and proper treatment are very important for pulmonary disfunction in patients with liver cirrhosis.

Key words: liver cirrhosis, pulmonary disfunction, hypoxemia, respiratory alkalosis

\author{
Mavija Zoran \\ Univerzitetski klinički centar Republike Srpske, \\ Banja Luka \\ Klinika za unutrašnje bolesti \\ Tel : +38751342660 \\ E-mail: zoranmavija@yahoo.com
}

